\title{
LIMITED OCCURRENCE OF RESISTANT RADISH (Raphanus sativus) TO AHAS-INHIBITING Herbicides IN ARgentina ${ }^{1}$
}

\author{
Ocorrência Limitada de Nabo-Silvestre (Raphanus sativus) Resistente aos Herbicidas Inibidores \\ de AHAS na Argentina
}

\author{
PANDOLFO, C.E. .2,3*, PRESOTTO, A. ${ }^{2,3}$, POVERENE, M..$^{2,3}$, and CANTAMUTTO, M..$^{2,3}$
}

\begin{abstract}
Radish has developed feral and weedy biotypes, which is a concern for agriculture around the world. In Argentina, it is one of the most widespread and troublesome crop weeds. In Brazil, this species has developed herbicide-resistance to acetohydroxyacid synthase (AHAS) inhibiting herbicides. The objective of this study was to record the presence of herbicide-resistant weedy radish plants in Argentina. In spring 2008, we found a small population of radish at the end of the flowering stage in an imidazolinone-tolerant canola field treated with imazethapyr. Screening and dose-response tests were conducted to two successive generations. They proved the biotype resistant status, and showed extensive survival (between 50 and $80 \%$ of control) to the application of a double dose of four AHAS-inhibiting herbicides from two different chemical families (imidazolinones and sulfonylureas). Dose-response assays exhibited very high resistance for imazethapyr $\left(\mathrm{LD}_{50}=2452.5 \mathrm{~g}\right.$ a.i. ha-, $\mathrm{GR}_{50}=2926.9 \mathrm{~g}$ a.i. ha-1) and intermediate for metsulfuron $\left(\mathrm{LD}_{50}=3.0 \mathrm{~g}\right.$ a.i. ha- ${ }^{-1}, \mathrm{GR}_{50}=43.2 \mathrm{~g}$ a.i. ha-1 $)$. The acquisition of cross-resistance to different herbicide families would confer an adaptive and invasive advantage in agricultural environments to this biotype. Due to the herbicide rotation conducted in the field, the dispersion of this biotype was restricted. This is the first report of resistance in weedy radish in Argentina.
\end{abstract}

Keywords: herbicide-resistance, imazethapyr, metsulfuron, dose-response.

\begin{abstract}
RESUMO-O nabo tornou-se feral, sendo uma preocupação para a agricultura em diversas partes do mundo. Na Argentina, é uma das plantas daninhas mais difundidas e problemáticas das culturas. No Brasil, essa espécie gerou biótipos resistentes aos herbicidas inibidores de AHAS. O objetivo deste estudo foi documentar a presença de nabo-silvestre com resistência na Argentina. Na primavera de 2008, observaram-se plantas de nabo nos últimos estádios de floração em um campo de canola tolerante aos herbicidas do grupo quimico das imidazolinonas, que havia recebido uma aplicação de imazethapyr. Testes de rastreio e dose-resposta foram conduzidos por duas gerações sucessivas, os quais provaram o status de biótipo resistente e mostraram alta sobrevivência (entre 50 e $80 \%$ de controle) na aplicação de dose dupla de quatro herbicidas inibidores da AHAS (duas famílias químicas diferentes: imidazolinonas e sulfonilureias). Os ensaios de dose-resposta exibiram resistência muito elevada para imazethapyr $\left(L D 50=2.452,5 \mathrm{~g}\right.$ i.a. $h \mathrm{a}^{-1}, G R 50=2.926,9 \mathrm{~g}$ i.a. ha $\left.\mathrm{H}^{-1}\right)$ e intermediária para metsulfuron $\left(L D_{50}=3.0 \mathrm{~g}\right.$ i.a. $h a^{-1}, G R_{50}=43.2 \mathrm{~g}$ i.a. $\left.h a^{-1}\right)$. A aquisiç̧ão de resistência cruzada para famílias de herbicidas diferentes proporcionaria uma vantagem adaptativa e invasiva em ambientes agrícolas para esse biótipo. Devido à rotação do herbicida conduzida no campo, a dispersão desse biótipo foi restringida. Esse é o primeiro relato de resistência em nabo-silvestre para a Argentina.
\end{abstract}

Palavras-chave: resistência a herbicidas, imazethapyr, metsulfuron, dose-resposta.

1 Recebido para publicação em 28.9.2012 e aprovado em 19.12.2012.

2 Consejo Nacional de Investigación Científica y Técnica (CERZOS-CONICET) 8000, Bahía Blanca, Argentina; ${ }^{3}$ Depto. de Agronomía, Universidad Nacional del Sur, San Andrés 800, 8000, Bahía Blanca, Argentina, <cpandolfo@cerzos-conicet.gob.ar>.

Planta Daninha, Viçosa-MG, v. 31, n. 3, p. 657-666, 2013 


\section{INTRODUCTION}

The Brassicaceae family is a wide taxonomic group that includes not only radish (Raphanus sativus) but also many other economically important crops, such as canola (Brassica napus) and cabbages (B. oleracea) and several cosmopolitan weeds, such as wild radish ( $R$. raphanistrum). Radish is an ancient crop domesticated for its edible roots, but sometimes it escapes from cultivation and forms weedy (feral) populations. This species and its wild relative are herbaceous plants, with annual or biennial life cycle, selfincompatibility and entomophilous pollination (Kaneko, 2011; Warwick, 2011). Radish is a noxious weed in the temperate zones of America and has been recognized as a serious problem in Brazil, Paraguay, and Chile (Theisen, 2008; Campbell \& Snow, 2009; Kaneko et al., 2011). In Argentina, it is known as 'nabón' and, together with wild radish, which is less frequent, are included in the most widespread and troublesome weeds of grain crops since the first decades of the $20^{\text {th }}$ century (Ibarra, 1937; Marzocca, 1976).

Both Raphanus spp. have developed herbicide-resistance to acetohydroxyacid synthase (AHAS) inhibiting herbicides (Hashem et al., 2001; Smit \& Cairns, 2001). In southern Brazil, a feral radish biotype with herbicide-resistance was reported by Theisen (2008).

There is a sustained increase in the occurrence of herbicide resistant weeds worldwide, and to date there have been reported 370 resistant biotypes in 200 species (116 dicots and 84 monocots) and over 570,000 infested habitats. AHAS-inhibiting herbicides comprise the most resistanceprone group, with the highest number of resistant biotypes in the last 10 years (Heap, 2012).

AHAS is the first common enzyme in the biosynthesis of the branched chain amino acids valine, leucine, and isoleucine, which are essential for plant development. Five chemical classes of commercial herbicides inhibit AHAS: sulfonylureas (SU), imidazolinones (IMI), triazolopyrimidines, pyrimidinylthio-benzoates, and sulfonylamino-carbonyltriazolinones. AHAS-inhibiting herbicides are widely used because of their low dose rate, low environmental impact, low mammalian toxicity, wide crop selectivity, and high control efficacy (Yu et al., 2003; Duggleby et al., 2008). The resistance evolution is generally due to a reduction in target site sensitivity conferred by one of several mutations within the AHAS gene (Holt et al., 1993; Yu et al., 2003).

Resistance denotes the inherited plant ability to survive and reproduce being exposed to an herbicide dosage substantially greater than those the wild type can withstand (Holt et al., 1993). It is an evolutionary process that involves the frequency increase of resistant individuals due to spontaneous mutations. The repeated use of the same herbicide kills susceptible plants, leaving only the resistant ones that reproduce without competition. Acknowledgement of the internal and external resistance factors involved in plant evolution allows to design mitigation strategies. An effective herbicide-resistance management depends on reducing the selection pressure, decreasing frequency, and amount of herbicide applied and rotating actives with different target sites. However, when multiply-resistant weed biotypes emerge, it cannot be managed simply by changing herbicides. Tools of integrated management practices include the application of non-chemical control techniques helped by models of resistance dynamics (Holt et al., 1993; Beckie, 2006).

Radish is a very common weed of grain crops in the southeastern Buenos Aires province (Marzocca, 1976). In this area, hormone herbicide application is declining in favor of the massive adoption of residual herbicides, such as metsulfuron, a SU applied during fallow and in the initial states of wheat development. Other residual AHAS-inhibiting herbicides are widely used in soybean (imazaquin, imazethapyr and chlorimuron) and maize (nicosulfuron, primisulfuron) (Leguizamón, 2009). The intense use of these herbicides is also a consequence of the availability of crops with genetic resistance to IMI herbicides, such as corn, sunflower, and canola, with Clearfield ${ }^{\circledR}(\mathrm{CL})$ technology (Beckie, 2006).

In southeastern Buenos Aires province intense selection pressure on weed populations due to repeated applications of herbicides with 
the same target sites could facilitate the emergence of resistant biotypes. The objective of this study was to document the presence of weedy radish plants with resistance to AHAS inhibiting herbicides in Argentina.

\section{MATERIALS AND METHODS}

\section{Habitat}

In spring 2008, we observed plants of weedy radish at the end of the flowering stage in an IMI-tolerant canola field treated with imazethapyr. The field was located in southeastern Buenos Aires province $\left(37.59^{\circ} \mathrm{S}\right.$, $\left.58.53^{\circ} \mathrm{W}\right)$.

The flora community composition was characterized using the Domin-Krajina semiquantitative scale (Mueller-Dombois \& Ellenberg, 1974) during the collection and in three successive years. Historical records of the field were provided by the technical managers of the farm.

\section{Generation advance and seed production}

A sample $(n>5 \%)$ of radish plants was collected and the seeds were considered the first generation of the RSBA3 biotype. First generation seedlings were grown in plastic trays with 200 cells of $12 \mathrm{~mL}$ containing a potting mix (Grow Mix ${ }^{\circledR}$ Terrafertil, with composted bark, peat moss, vermiculite, calcite, and dolomite) under greenhouse conditions at $20 \pm 5{ }^{\circ} \mathrm{C}$ and watered twice daily. After a month, seedlings were transplanted to the experimental field (Department of Agronomy, Universidad Nacional del Sur, $38.69^{\circ} \mathrm{S}, 62.25^{\circ} \mathrm{W}$ ) at the 1.2 to 1.3 decimal code growth stage (Madafiglio et al., 1999). The population ( $n>300$ plants) was grown completely isolated from other Raphanus spp. in an insect exclusion mesh cage of $10 \mathrm{~m} \times 12 \mathrm{~m} \times 2.8 \mathrm{~m}$. In order to promote pollination, polyphagous dipterous were released inside the cage weekly. The collected seed was considered the second generation.

\section{Control biotype}

First generation seeds of an herbicidesusceptible population (RSBA1) were collected in southwestern Buenos Aires province $\left(37.89^{\circ} \mathrm{S}, 61.87^{\circ} \mathrm{W}\right)$ where there was no known herbicide selection. At the time of collection, the population had a medium size ( $\mathrm{n}>300$ plants) and it was extended along Highway 76 edge. RSBA1 second generation seeds were generated under the previously detailed conditions but without the exclusion of natural pollinators.

\section{Experiment 1: exploratory test}

The response to imazethapyr in the first generation of both radish biotypes was evaluated on a wide number of individuals $(n>300)$. Two canola varieties were used as the control, one conventional NGOSP ('SW Gospel', Sursem Co.) and one with IMI resistance N8450 ('Nexera 8450', Dow Agrosciences Co.). Seedlings were grown in the greenhouse under the previously described conditions.

Imazethapyr (Pivot $\mathbb{R}, 100$ g a.i. $\mathrm{L}^{-1}$, BASF Argentina Co.) plus $0.5 \%$ alcohol ethoxylate adjuvant (Sandowett $\mathbb{R}$, $500 \mathrm{~g}$ a.i. L $\mathrm{L}^{-1}$, Syngenta Agro Co.) was applied 25 and 67 days after emergence (DAE), at the 1.2 to 1.4 growth stage at $64 \mathrm{~g}$ a.i. ha-1 and $160 \mathrm{~g}$ a.i. ha ${ }^{-1}$. The spray was done with flat spray tips (TeeJet $\mathbb{R} 8001$ EUB), at $2.6 \mathrm{~km} \mathrm{~h}^{-1}$ speed, $175 \mathrm{~L} \mathrm{ha}^{-1}$ caudal with an impact of 33 drops $\mathrm{cm}^{-2}(80 \%$ with a size below $250 \mu \mathrm{m})$. Irrigation was excluded $24 \mathrm{~h}$ after each application to avoid leaching off the active ingredient.

Plant survival was evaluated 35 days after the last application (DAT). Plants were classified as herbicide survivors if the growing point remained alive (Walsh et al., 2004). The response to the herbicide was expressed as percent of survival and the biotypes were designated as resistant if $20 \%$ of the individuals survived the recommended field application herbicide rate as described by Moss et al. (1999). The frequency data were analyzed using chi-square contingency table (2 by 2) tests with Infostat 2012 software (Di Rienzo et al., 2012).

\section{Experiment 2: broad screening test}

The response of the second radish generation to a range of six herbicides was estimated. Two varieties of canola were used as the control: a conventional N1700 
('Nexera 1700', Dow Agrosciences Co.) and an IMI resistant N8450 ('Nexera 8450', Dow Agrosciences Co.).

Seedlings were established by sowing 10 seeds into $15-\mathrm{cm}$-diam plastic pots containing $75 \%$ soil and $25 \%$ potting mix. The pots were maintained in the greenhouse at $20 \pm 5{ }^{\circ} \mathrm{C}$, watered twice daily and fertilized with a liquid fertilizer (Chase LI ${ }^{\circledR}$, grade 5-3-3) at 5.7 $\mathrm{L} \mathrm{ha}^{-1}$ 57 DAE.

The applied herbicides were representative of two AHAS-inhibiting families: IMI (imazethapyr, imazamox) and SU (metsulfuron, iodosulfuron); and two families with different mode of action (glyphosate and 2,4-D) (MallorySmith \& Retzinger, 2003) (Table 1).

Herbicides were applied at double recommended rate (2X) $53 \mathrm{DAE}$ at the 1.3-1.4 growth stage, using a backpack sprayer equipped with flat spray tips (TeeJet $\mathbb{R}$ $8004 \mathrm{EVB})$, at $4 \mathrm{~km} \mathrm{~h}^{-1}$ and calibrated to deliver $188 \mathrm{~L} \mathrm{ha}^{-1}$. Alkylaryl polyglycol ether adjuvant (Canaplus $1050 \mathbb{R}$, $500 \mathrm{~g}$ a.i. $\mathrm{L}^{-1}$, Canamex Argentina S.A.) was added at the recommended dose $(0.25 \%)$. Irrigation was excluded $24 \mathrm{~h}$ after herbicide application in order to avoid leaching off the active ingredient.

Plant response was evaluated 35 DAT using a visual scale that classified the individual damage into the following categories: $1=$ no damage, $2=\leq 25 \%$ leaf damage, $3=26-75 \%$ leaf damage, $4=>75 \%$ leaf damage or dead apex, 5 = dead plant (Moss et al., 1999; Hashem et al., 2001). Plant survival index was calculated using the damage assessed weighted by plant number in each category, according to:

Survival index $=\left(P N_{1} \times 1+P N_{2} \times 0.75+P N_{3} \times 0.5\right) / N$, where $P N_{n}=$ plant number with $n$ category ( $n=1-3)$ and $N=$ plant number per plot. The survival index was expressed as the proportion of the untreated control mean for each biotype.

Above-ground plant tissue was harvested 40 DAT, and dried at $40{ }^{\circ} \mathrm{C}$ until constant weight. The dry matter weight was expressed as a percentage of the untreated control. The experiment was arranged as a completely randomized design, with four replications. The data was transformed by:

$$
y=\arcsin (x+0.5)^{1 / 2}
$$

ANOVA analysis and a mean comparison Tukey's test were conducted with Infostat 2012 software.

\section{Experiment 3: dose-response assay}

A detailed dose-response experiment was conducted with imazethapyr at $0.0,10.0,20.0$, 50.0, 100.1, 200.2, 500.5, $1001.0 \mathrm{~g}$ a.i. ha $\mathrm{h}^{-1}$ and metsulfuron at $0.0,0.6,1.2,3.0,6.0,12.0,30.0$, $60.0 \mathrm{~g}$ a.i. ha ${ }^{-1}$. This doses corresponds to $0,1 /$ $10,1 / 5,1 / 2,1,2,5$ and tenfold the commercial field rate $(\mathrm{X})$.

Plant growth and herbicide applications were done as in experiment 2.

Herbicides were applied 29 DAE at the 1.4 to 1.6 growth stage, using a experimental backpack sprayer equipped with extended range flat spray tips (TeeJet $\mathbb{R}$ XR8004 VB), at $4.5 \mathrm{~km} \mathrm{~h}^{-1}$ and calibrated to deliver $184 \mathrm{~L} \mathrm{ha}^{-1}$. Alkylaryl polyglycol ether adjuvant was added at the recommended dose $(0.25 \%)$.

At 27 and 35 DAT plant survival and above-ground plant dry matter were evaluate as in experiment 2 .

Table 1 - Herbicides applied to the second generation of two radish biotypes and recommended field rate

\begin{tabular}{|l|l|l|l|r|r|}
\hline Herbicide & Chemical family & Trade name & Company & Formulation a.i. & $\begin{array}{c}\text { Rate } \\
(\mathrm{g} \text { a.i. ha }\end{array}$ \\
\hline Imazethapyr & Imidazolinone & Pivot 70DG & BASF & $700 \mathrm{~g} \mathrm{~kg}^{-1}$ & 100.0 \\
\hline Imazamox & & Sweeper 70DG & BASF & $700 \mathrm{~g} \mathrm{~kg}^{-1}$ & 49.0 \\
\hline Metsulfuron & Sulfonylurea & Generic & Generic & $600 \mathrm{~g} \mathrm{~kg}^{-1}$ & 6.0 \\
\hline Iodosulfuron & & Hussar & Bayer & $53 \mathrm{~g} \mathrm{~kg}^{-1}$ & 3.2 \\
\hline Glyphosate & None & Roundup & Monsanto & $480 \mathrm{~g} \mathrm{~L}^{-1}$ & 1440.0 \\
\hline 2,4-D & Phenoxy & Generic & Generic & $602 \mathrm{~g} \mathrm{~L}^{-1}$ & 602.0 \\
\hline
\end{tabular}


Data fitted a non-linear log-logistic regression model with three parameters, and dose-response curves were made using the drc package of the R2.15.0 statistical software (R Development Core Team, 2012). The effective dose required for $50 \%$ plant injury $\left(\mathrm{LD}_{50}\right)$ and the effective dose required for $50 \%$ reduction in plant biomass $\left(\mathrm{GR}_{50}\right)$ were estimated. This values were used to calculate the resistance factor $(R F)$, defined as the ratio between LD50 and GR50 values of the resistant and susceptible biotypes $\left(\mathrm{ED}_{50} \mathrm{R} / \mathrm{ED}_{50} \mathrm{~S}\right)$.

Log-logistic model equation used was:

$$
Y=d / 1+(x / e)^{b}
$$

where $Y$ is the percent survival or the dry matter weight, $e$ is the $\mathrm{ED}_{50}\left(\mathrm{LD}_{50}\right.$ or $\left.\mathrm{GR}_{50}\right), d$ is the coefficient corresponding to the upper curve limit, $b$ is the response line slope around $e$, and $x$ (independent variable) is the herbicide dose. The lower limit was fixed in 0 (3 parameters) (Seefeldt et al., 1995; Knezevic et al., 2007).

\section{RESULTS AND DISCUSSION}

\section{Habitat}

Before 2008, the basic crop rotation was wheat-soybean, with only one sunflower crop within the ten previous years. The herbicide use register included three SU but none IMI application. The field was under no-till system since 2001, glyphosate and 2.4-D were applied during fallows. Wheat crop weeds were controlled with dicamba and metsulfuron and glyphosate was applied to RR soybean. There were no repeated applications of SU herbicides in two consecutive years. An IMI herbicide was applied once to canola during 2008.

In spring 2008, RSBA3 was found in a small group $(\mathrm{n}<50)$ within a Nexera 8450 canola crop. The group formed a semicircular patch $\left(<5 \mathrm{~m}^{2}\right)$ placed $50 \mathrm{~m}$ of the northeastern edge of a 40 ha rectangular field. A natural population composed of Brassicaceae species was extended over the field fence in a hemirectangular uncultivated patch of $800 \mathrm{~m}^{2}$. The plant community in this patch was composed by shortpod mustard (Hirschfeldia incana), which was the most abundant species with $40-50 \%$ plant coverage, birdsrape (Brassica rapa) and radish, with $<30 \%$ coverage.
The next spring (2009), the field showed a sparse presence of RSBA3 plants reaching the reproductive stage, within a wheat crop. The radish population was small $(n<100)$ and spread throughout the field, scattered $<250 \mathrm{~m}$ around the same patch where it was observed the previous growing season. The wheat crop had been sprayed with $7 \mathrm{~g} \mathrm{ha}^{-1}$ metsulfuron. The same situation was observed in 2011 when RSBA3 survived the same herbicide and dose in a wheat crop and the population size was less than 100 individuals. In the three summers after the first observation, the field was cultivated with RR soybean and sprayed with glyphosate. The presence of radish in the natural plant community in the uncultivated field edge was observed again in 2011. Shortpod mustard showed $50-75 \%$ plant coverage, while radish reached $10 \%$. Birdsrape was present too, with less than $1 \%$ coverage.

\section{Experiment 1: exploratory test}

More than $85 \%$ of RSBA3 first generation plants survived imazethapyr applications, without any toxicity symptoms. In contrast, herbicides killed more than $85 \%$ RSBA 1 and the conventional canola NGOSP, both significantly different from the RSBA3 biotype $\left(x^{2} \mathrm{p}<0.001\right)$. IMI-tolerant canola showed complete survival and overcame the RSBA3 biotype $\left(x^{2} \mathrm{p}<0.001\right)$.

\section{Experiment 2: broad screening test}

RSBA3 biotype showed high plant survival for both IMI herbicides. In contrast, RSBA1 biotype was susceptible to all the studied herbicides, with no statistical differences from conventional canola N1700 (Table 2).

The RSBA3 radish biotype showed more than $50 \%$ plant survival to double dose of imazethapyr, differing $(\mathrm{p}<0.05)$ from RSBA1 and N1700, wich were completely killed by this herbicide. IMI-tolerant canola (N8450) was not affected by imazethapyr. Similar results were observed for imazamox, although RSBA3 had more than $75 \%$ plant survival.

Metsulfuron reduced N8450 plant survival, showing no significant differences $(p<0.05)$ with RSBA1 and N1700. RSBA3 plant survival to this herbicide was more than $50 \%$. Effects 
Table 2 - Plant survival index and dry matter accumulation expressed as a percentage of the untreated control (mean \pm standard error) of the RSBA3 herbicide-resistant weedy radish biotype compared with RSBA1 susceptible biotype, N1700 conventional and N8450 IMI-tolerant canola cultivars treated with six herbicides at double the commercial dose (2X)

\begin{tabular}{|l|c|c|c|c|c|c|c|c|}
\hline \multirow{2}{*}{ Herbicide } & \multicolumn{4}{|c|}{ Plant survival index } & \multicolumn{4}{c|}{ Dry matter } \\
\cline { 2 - 9 } & RSBA1 & RSBA3 & N1700 & N8450 & RSBA1 & RSBA3 & N1700 & N8450 \\
\hline Imazethapyr & $0.0 \pm 0.0 \mathrm{a}$ & $66.9 \pm 4.3 \mathrm{~b}$ & $0.0 \pm 0.0 \mathrm{a}$ & $100.0 \pm 0.0 \mathrm{c}$ & $14.1 \pm 2.9 \mathrm{a}$ & $49.0 \pm 5.5 \mathrm{~b}$ & $29.6 \pm 9.9 \mathrm{ab}$ & $97.4 \pm 7.4 \mathrm{c}$ \\
\hline Imazamox & $0.0 \pm 0.0 \mathrm{a}$ & $86.9 \pm 4.3 \mathrm{~b}$ & $0.0 \pm 0.0 \mathrm{a}$ & $100.0 \pm 0.0 \mathrm{c}$ & $32.9 \pm 3.7 \mathrm{a}$ & $67.4 \pm 2.1 \mathrm{~b}$ & $35.7 \pm 5.1 \mathrm{a}$ & $113.7 \pm 7.5 \mathrm{c}$ \\
\hline Metsulfuron & $0.0 \pm 0.0 \mathrm{a}$ & $56.9 \pm 11.2 \mathrm{~b}$ & $0.0 \pm 0.0 \mathrm{a}$ & $7.5 \pm 7.5 \mathrm{a}$ & $14.5 \pm 5.8 \mathrm{a}$ & $60.6 \pm 15.0 \mathrm{ab}$ & $32.3 \pm 5.6 \mathrm{a}$ & $100.7 \pm 21.8 \mathrm{~b}$ \\
\hline Iodosulfuron & $0.0 \pm 0.0 \mathrm{a}$ & $87.5 \pm 4.8 \mathrm{~b}$ & $0.0 \pm 0.0 \mathrm{a}$ & $97.5 \pm 1.0 \mathrm{c}$ & $43.8 \pm 6.7 \mathrm{a}$ & $68.6 \pm 7.0 \mathrm{ab}$ & $44.2 \pm 2.5 \mathrm{a}$ & $92.7 \pm 8.9 \mathrm{~b}$ \\
\hline 2.4-D & $0.0 \pm 0.0 \mathrm{a}$ & $0.0+0.0 \mathrm{a}$ & $0.0 \pm 0.0 \mathrm{a}$ & $0.0 \pm 0.0 \mathrm{a}$ & $0.0 \pm 0.0 \mathrm{a}$ & $0.0 \pm 0.0 \mathrm{a}$ & $0.0 \pm 0.0 \mathrm{a}$ & $0.0 \pm 0.0 \mathrm{a}$ \\
\hline Glyphosate & $3.8 \pm 2.4 \mathrm{a}$ & $0.0 \pm 0.0 \mathrm{a}$ & $0.0 \pm 0.0 \mathrm{a}$ & $0.0 \pm 0.0 \mathrm{a}$ & $3.8 \pm 2.4 \mathrm{a}$ & $0.0 \pm 0.0 \mathrm{a}$ & $0.0 \pm 0.0 \mathrm{a}$ & $0.0 \pm 0.0 \mathrm{a}$ \\
\hline
\end{tabular}

In each row, different letters indicate significant differences according to Tukey's test $(\mathrm{p}<0.05)$.

were similar for iodosulfuron, with an even greater survival of the resistant biotype and without effects on N8450, which survived the herbicide treatment.

Glyphosate and 2,4-D produced the complete mortality of all the studied biotypes. The scarce surviving RSBA1 radish plants were not statistically different from other biotypes that were completely killed.

Biomass accumulation in N8450 rose above $90 \%$ with SU and IMI. RSBA1 was highly affected by both group of herbicides. IMI herbicides reduced around $50 \%$ of RSBA3 dry matter, and was significantly different to RSBA1. SU herbicides produced a similar reduction of dry matter in the resistant biotype but could not be distinguish from RSBA1 and conventional canola.

Dry matter accumulation reduction caused by glyphosate and 2,4-D was complete in all biotypes.

\section{Experiment 3: dose-response assay}

Dose-response studies revealed that the RSBA3 biotype was highly resistant to imazethapyr (Figure 1) with more than 65\% plant survival at fivefold the commercial dose (500.5 g a.i. ha ${ }^{-1}$ ). In contrast, the survival of the susceptible biotype RSBA1 was reduced by $85 \%$ at the lower dose (14.3 $\mathrm{g}$ a.i. ha $\left.\mathrm{h}^{-1}\right)$. This biotype $\mathrm{LD}_{50}$ was $0.04 \mathrm{X}\left(4.0 \mathrm{~g}\right.$ a.i. ha $\left.{ }^{-1}\right)$ while RSBA3 value was higher than $24 \mathrm{X}\left(2452.5 \mathrm{~g}\right.$ a.i. ha $\left.{ }^{-1}\right)$. The resistance factor was over 600 (Table 3).

These results were similar to those obtained for dry matter accumulation (Figure 2).
With only a $10 \%$ commercial field rate, RSBA1 dry matter was reduced by $80 \%$, and more that $95 \%$ at half dose. In contrast, the application of imazethapyr in RSBA3 did not produce statistically reduction even at the highest dose (1001.0 g a.i. ha ${ }^{1}$, tenfold commercial field rate). Estimated $\mathrm{GR}_{50}$ for this population was 29.24X (2926.9 g a.i. ha-1), and for RSBA1 was $0.03 \mathrm{X}\left(3.0 \mathrm{~g}\right.$ a.i. $\left.\mathrm{ha}^{1}\right)$ resulting in a resistance factor higher than 900 .

Dose-response assays showed that RSBA3 had an intermediate resistance to metsulfuron

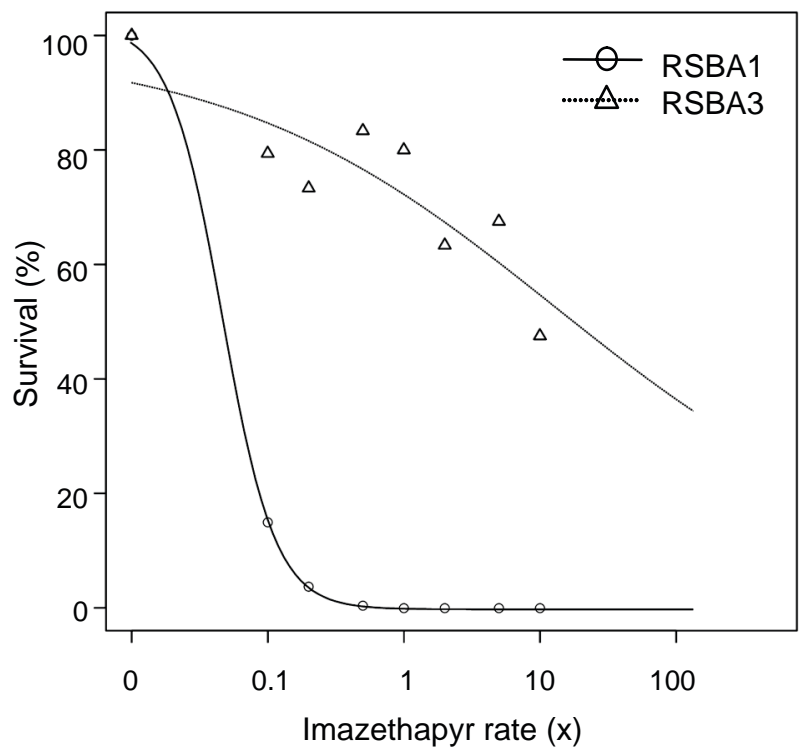

Figure 1 - Response of the susceptible RSBA1 (O) and the resistant RSBA3 $(\Delta)$ weedy radish biotypes to the application of imazethapyr, expressed as percent survival. Each point represents the mean of four replicates containing 10 plants. 
Table 3 - Estimated parameters for non-linear regression equations of resistant (RSBA3) and susceptible (RSBA1) radish biotypes survival index to the application of AHAS-inhibiting herbicides. Comparative levels of resistance were estimated

\begin{tabular}{|c|c|c|c|c|c|c|}
\hline Herbicide & Biotype & $\mathrm{b}$ & $\mathrm{d}$ & LD $_{50}$ & $\mathrm{P}$ & $\mathrm{RF}$ \\
\hline \multirow{2}{*}{ Imazethapyr } & RSBA1 & 1.96 & 100.01 & 0.04 & 0.5235 & 612.5 \\
\cline { 2 - 8 } & RSBA3 & 0.32 & 9.62 & 24.50 & & \\
\hline \multirow{2}{*}{ Metsulfuron } & RSBA1 & 2.20 & 100.05 & 0.04 & 0.9160 & 12.7 \\
\cline { 2 - 8 } & RSBA3 & 0.86 & 100.65 & 0.51 & & \\
\hline
\end{tabular}

Parameters: $\mathrm{b}=$ slope of the curve, $\mathrm{d}=$ upper limit, $\mathrm{LD}_{50}=$ effective dose required for $50 \%, \mathrm{p}=$ model adjust, $\mathrm{RF}=$ resistance factor $\left(\mathrm{LD}_{50} \mathrm{R} / \mathrm{LD}_{50} \mathrm{~S}\right)$.

(Figure 3). The survival of this biotype was not reduced to less than $40 \%$ at the commercial rate $\left(6.0 \mathrm{~g}^{\mathrm{a}}\right.$.i. $\left.\mathrm{ha}^{-1}\right)$ and was higher than $15 \%$ even at fivefold dose (30.0 g a.i. ha $\left.{ }^{-1}\right)$. These results were more notable when compared with RSBA1, in which survival was reduced by approx. $85 \%$ at the lowest dose $\left(0.6 \mathrm{~g}\right.$ a.i. ha $\left.\mathrm{h}^{-1}\right)$ and approx. $1 \%$ with only $1 / 5$ of the commercial field rate $\left(1.2 \mathrm{~g}\right.$ a.i. ha $\left.{ }^{-1}\right)$. The $\mathrm{RSBA} 3 \mathrm{LD}_{50}$ was $0.51 \mathrm{X}\left(3.0 \mathrm{~g}\right.$ a.i. $\left.\mathrm{ha}^{-1}\right)$, indicating an increased resistance of at least twelvefold over RSBA1 which $L_{50}$ was $0.04 X\left(0.2\right.$ g a.i. ha ${ }^{-1}$ ) (Table 4).

These results were confirmed by dry matter reduction analysis. RSBA3 was less affected by high metsulfuron doses than what was

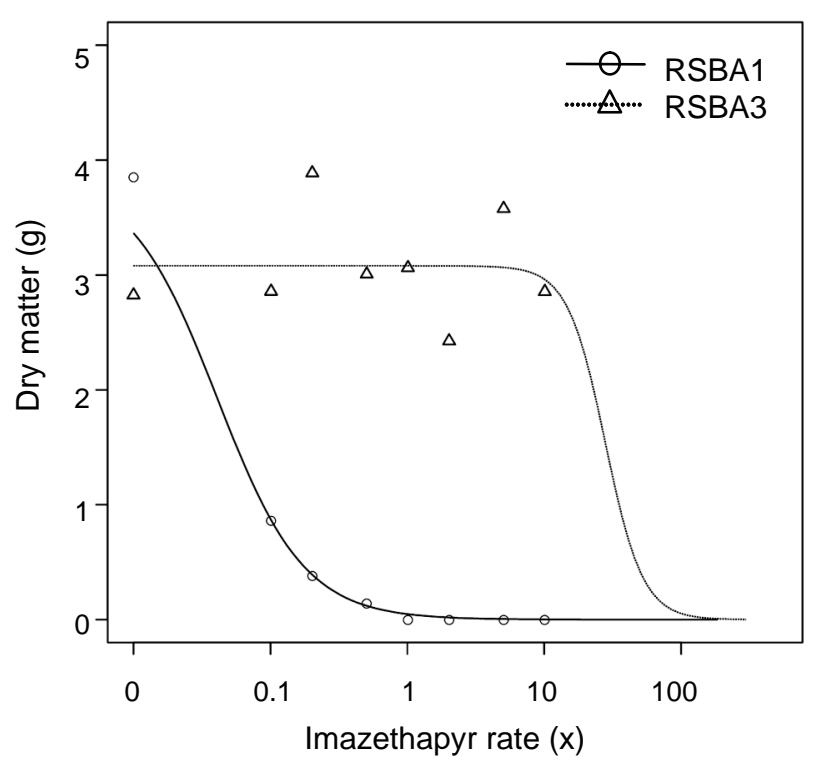

Figure 2 - Response of the susceptible RSBA1 (O) and the resistant RSBA3 $(\Delta)$ weedy radish biotypes to the application of imazethapyr, expressed as remnant dry matter. Each point represents the mean of four replicates containing 10 plants. estimated for plant survival, due to rapid leaf tissue recovery and regrowth. Dry matter RSBA3 accumulation was reduced below $70 \%$ only at tenfold commercial dose (60.0 g a.i. ha-1) while in RSBA1 1/ 10 dose was enough to reduce over $85 \%$ this value. This resulted in a $\mathrm{GR}_{50}$ of $0.05 \mathrm{X}\left(0.3 \mathrm{~g}\right.$ a.i. $\left.\mathrm{ha}^{-1}\right)$ for this biotype, and $7.20 \mathrm{X}$ (43.2 $\mathrm{g}$ a.i. $\mathrm{ha}^{-1}$ ) for RSBA3, with a resistance factor above 140 (Figure 4).

Resistance to IMI herbicides was observed in two RSBA3 successive generations, without herbicide selection, proving the heritable nature of the trait. The screening test showed a broad herbicide-resistance to actives with the same target site. RSBA3 second generation was

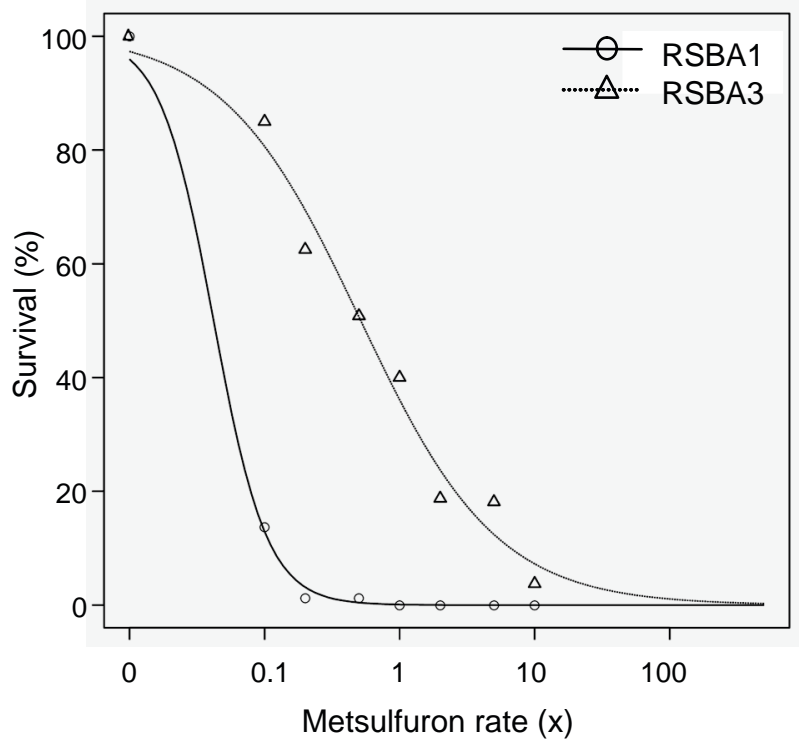

Figure 3 - Response of the susceptible RSBA1 (O) and the resistant RSBA3 $(\Delta)$ weedy radish biotypes to the application of metsulfuron, expressed as percent survival. Each point represents the mean of four replicates containing 10 plants. 
Table 4 - Estimated parameters for non-linear regression equations comparing the remnant dry matter of susceptible (RSBA1) and resistant (RSBA3) radish biotypes following the application of AHAS-inhibiting herbicides. Comparative levels of resistance were estimated

\begin{tabular}{|c|c|c|c|c|c|c|}
\hline Herbicide & Biotype & $\mathrm{b}$ & $\mathrm{d}$ & GR $_{50}$ & $\mathrm{P}$ & RF \\
\hline \multirow{2}{*}{ Imazethapyr } & RSBA1 & 1.24 & 3.85 & 0.03 & 0.5202 & 974.7 \\
\cline { 2 - 8 } & RSBA3 & 3.01 & 3.08 & 29.24 & & \\
\hline \multirow{2}{*}{ Metsulfuron } & RSBA1 & 1.89 & 3.85 & 0.05 & 0.6543 & 144.0 \\
\cline { 2 - 8 } & RSBA3 & 0.76 & 3.27 & 7.20 & & \\
\hline
\end{tabular}

Parameters: $\mathrm{b}=$ slope of the curve, $\mathrm{d}=$ upper limit, $\mathrm{GR}_{50}=$ effective dose required for $50 \%, \mathrm{p}=$ model adjust, $\mathrm{RF}=$ resistance factor $\left(\mathrm{GR}_{50} \mathrm{R} / \mathrm{GR}_{50} \mathrm{~S}\right)$

resistant to at least four AHAS-inhibiting herbicide applications of two different chemical families (IMI and SU). Dose-response assays confirmed this observation, showing that resistance was very high for imazethapyr, and intermediate for metsulfuron. The resistant biotype was highly susceptible to glyphosate and 2,4-D at commercial doses.

The small resistant biotype population was observed in a field with a large agricultural and herbicide usage history. The low size of this population might be addressed to a recent mutational event, without selection. This situation is in accordance with the model proposed by Richter et al. (2002), which states

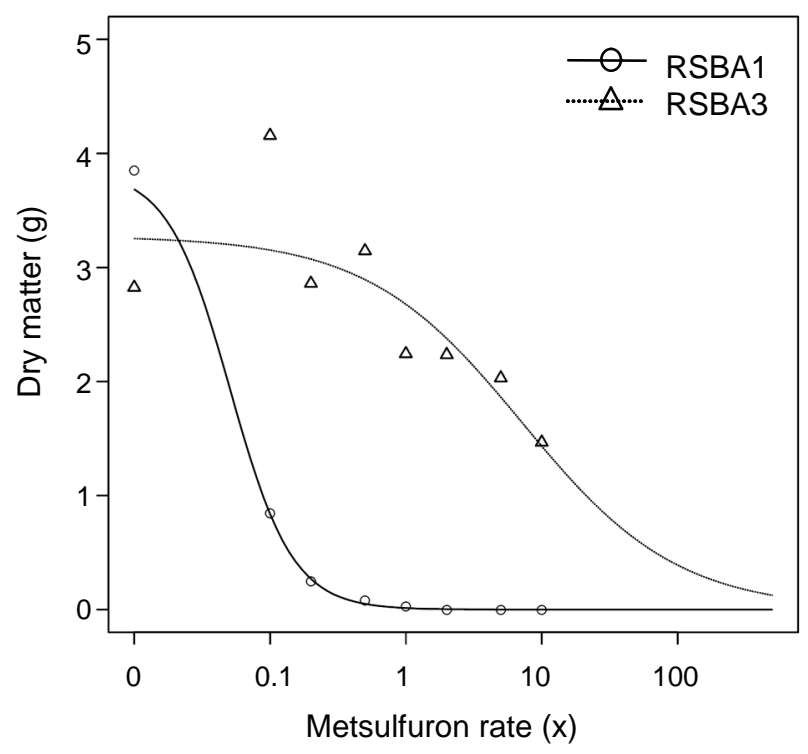

Figure 4 - Response of the susceptible RSBA1 (O) and the resistant RSBA3 $(\Delta)$ weedy radish biotypes to the application of metsulfuron, expressed as remnant dry matter. Each point represents the mean of four replicates containing 10 plants. that the build-up of target-site resistance in a field often occurs in a step-wise manner. Usually, resistant weeds are not noticed by the farmer until approx. 30\% plants in a field are resistant. Only if a certain frequency of resistant plants is reached does rapid multiplication and spatial resistance spreading occur. This could also explain why this biotype resistance level was not total, since resistance may not be stabilized. Chi-square goodness of fit for the RSBA3 second generation resistance fit a 3:1 ratio $\left(x^{2}\right.$ p $>0.20$ in Exp. 2 and $x^{2} p>0.10$ in Exp. 3$)$, suggesting the segregation of one dominant gene.

Resistance magnitudes to different AHASinhibiting herbicides could vary widely among amino acid substitutions of the enzyme. In SU resistant biotypes, resistance to one herbicide has not guaranteed cross-resistance to all the members of that chemical family (Tranel \& Wright, 2002). This situation may explain the intermediate levels of metsulfuron resistance and the high iodosulfuron and IMI herbicides resistance levels of RSBA3.

The RSBA3 plants did not become a management problem for the farmer probably because of the use of alternative herbicides, such as 2,4-D and glyphosate, which avoid the frequency increase of the resistant trait.

The presence of an extended radish natural population along the field margin might have acted as a refuge for the susceptible trait. It has been proposed that analogous to the refuge tactic in Bt crops, herbicide susceptible weed refuges might be a tactic to delay herbicideresistance evolution (Richter et al., 2002; Beckie, 2006). Such plants could dilute the resistance allele frequency in a population by gene flow. However, other authors consider that 
herbicide susceptible refuges would not be effective because recessive resistance in outcrossing weed species is rare (Beckie, 2006). Anyway, population genetic models suggest that the spread of resistance is always greatly delayed by a heterogeneous environment. The fate of a resistance allele may depend on the balance between herbicide treatment favoring the resistance and the capacity to maintain the resistance gene in untreated years or areas (Richter et al., 2002; Roux \& Reboud, 2007).

Theisen (2008) confirmed the presence of a radish biotype with cross-resistance to metsulfuron-methyl, chlorimuron-ethyl, clorasulam-methyl and imazethapyr (two SU, a triazolpirimidina and an imidazolinone) in southern Brazil.

This is the first report of weedy radish resistance in Argentina. IMI and SU herbicide resistant alleles are present in the Argentine radish biodiversity. Dispersion and magnification of a biotype with this mutation will depend on the agronomic management of the agriculture systems. An appropriate herbicide rotation could minimize the occurrence of uncontrolled weeds. Our findings alert us about the importance to address herbicide usage in environmental management in order to avoid the selection of resistant individuals that are already present in the weedy radish populations.

\section{ACKNOWLEDGEMENTS}

We would like to thank Dow AgroSciences Co. and BASF Argentina Co. for their support of this research. We also thank Ings. Fernando Giachetti, Martín Herrera Vega, and Daniel Rolón for their assistance, as well as La Isaura Co. for letting us conduct our research in their field. We gratefully acknowledge the National Research Council of Argentina (CONICET) for the fellowship given to CEP and AP.

\section{LITERATURE CITED}

BECKIE, H. J. Herbicide-resistant weeds: management tactics and practices. Weed Technol., v. 20, n. 3, p. 793-814, 2006.

CAMPBELL, L. G; SNOW, A. A. Can feral weeds evolve from cultivated radish (Raphanus sativus, Brassicaceae)? Am. J. Bot., v. 96, n. 2, p. 498-506, 2009.
DI RIENZO, J. A. et al. Infostat versión 2012. Córdoba: Grupo InfoStat, FCA, Universidad Nacional de Córdoba, Argentina. http://www.infostat.com.ar

DUGGLEBY, R. G; MCCOURT, J. A.; GUDDAT, L. W. Structure and mechanism of inhibition of plant acetohydroxyacid synthase. Plant Physiol. Biochem., v. 46, n. 3, p. 309-324, 2008.

HASHEM, A. et al. Resistance of wild radish (Raphanus raphanistrum) to acetolactate synthase-inhibiting herbicides in the Western Australia wheat belt. Weed Technol., v. 15, n. 1, p. $68-74,2001$

HEAP, I. International survey of herbicide resistant weeds. Available in: $<$ http://www. weedscience. org $>$. Access 5 jul., 2012.

HOLT, J. S.; POWLES, S. B.; HOLTUM, J. A. M. Mechanisms and agronomic aspects of herbicide resistance. Ann. Rev. Plant Physiol. Plant Molec. Biol., v. 44, n. 1, p. 203-229, 1993.

IBARRA, F. E. Malezas más comunes del trigo y del lino. In: Almanaque del Ministerio de Agricultura, 1937. p. 405410 .

KANEKO, Y.; BANG, S. W.; MATSUZAWA, Y. Raphanus. In: KOLE, C. (Ed.). Wild crop relatives: genomic and breeding resources, vegetables. Berlin: Springer Berlin Heidelberg, 2011. p. 247-258.

KNEZEVIC, S. Z.; STREIBIG, J. C.; RITZ, C. Utilizing R software package for dose-response studies: the concept and data analysis. Weed Technol., v. 21, n. 3, p. 840-848, 2007.

LEGUIZAMÓN, E. S. Herbicidas. La agricultura y el manejo de las malezas en la región pampeana. In: RICCI, D. (Ed.). La Argentina 2050. La revolución tecnológica del agro. Buenos Aires: CASAFE, 2009. p. 400-416.

MADAFIGLIO, G. P.; MEDD, R. W.; CORNISH, P. S. A decimal code for the growth and development stages of wild radish (Raphanus raphanistrum L.). Plant Protec. Quart., v. 14 , n. 4, p. 143-146, 1999

MALLORY-SMITH, C. A.; RETZINGER, E. J. Revised classification of herbicides by site of action for weed resistance management strategies. Weed Technol., v. 17, n. 1, p. 605-619, 2003.

MARZOCCA, A. Manual de malezas. 3.ed. Buenos Aires: Hemisferio Sur, 1976. 552 p.

MOSS, S. R. et al. The occurrence of herbicide-resistant grass-weeds in the United Kingdom and a new system for designating resistance in screening assays. In: BRIGHTON CROP PROTECTION CONFERENCE: WEEDS, 1999, Brighton. Proceedings... Brighton: 1999. p. 179-184.

Planta Daninha, Viçosa-MG, v. 31, n. 3, p. 657-666, 2013 
MUELLER-DOMBOIS, D; ELLENBERG, H. Aims and methods of vegetation ecology. New York: Wiley, 1974. $547 \mathrm{p}$.

R DEVELOPMENT CORE TEAM. R: A language and environment for statistical computing. Vienna: $\mathrm{R}$ Foundation for Statistical Computing, 2012.

RICHTER, O.; ZWERGER, P.; BÖTTCHER, U. Modelling spatio-temporal dynamics of herbicide resistance. Weed Res., v. 42, n. 1, p. $52-64,2002$.

ROUX, F.; REBOUD, X. Herbicide resistance dynamics in a spatially heterogeneous environment. Crop Protec., v. 26, n. 3, p. 335-341, 2007.

SEEFELDT, S. S.; JENSEN, J. E.; PATRICK FUERST, E. Log-logistic analysis of herbicide dose-response relationships Weed Technol., v. 9, n. 2, p. 218-225, 1995

SMIT, J. J.; CAIRNS, A. L. P. Resistance of Raphanus raphanistrum to chlorsulfuron in the Republic of South Africa. Weed Res., v. 41, n. 1, p. 41-47, 2001
THEISEN, G. Aspectos botânicos e relato da resistência de nabo silvestre aos herbicidas inibidores de ALS Pelotas: Embrapa Clima Temperado, 2008. 26 p.

TRANEL, P. J.; WRIGHT, T. R. Resistance of weeds to ALS-inhibiting herbicides: what have we learned? Weed Sci., v. 50, n. 6, p. $700-712,2002$

WALSH, M. J. et al. Multiple-herbicide resistance across four modes of action in wild radish (Raphanus raphanistrum).

Weed Sci., v. 52, n. 1, p. 8-13, 2004.

WARWICK, S. I. Brassicaceae in agriculture. In SCHMIDT, R.; BANCROFT, I. (Eds.). Genetics and genomics of the brassicaceae. New York: Springer, 2011. p. $33-65$.

YU, Q. et al. ALS gene proline (197) mutations confer ALS herbicide resistance in eight separated wild radish (Raphanus raphanistrum) populations. Weed Sci., v. 51, n. 6, p. $831-838,2003$ 